\title{
The
}

University

of Chicago

Law Review

VOLUME 40 NUMBER 3 SPRING 1973

\section{The National Court of Appeals: Another Dissent}

William J. Brennan, Jr.†

Several years ago I came to appreciate the wisdom of some of my distinguished predecessors who believed that a Justice of the Supreme Court should speak only through his published opinions. Since that time, with one important exception, I have made no speeches, written no articles, and engaged in no outside activities. The important exception relates to my role as Circuit Justice. In that role I should, and do, report directly to this Circuit Conference on the work of the Court. Moreover, those of my predecessors who declined to make speeches nevertheless believed, as I do, that a Justice should make known his views on proposals that would fundamentally alter the functions and procedures of the Court. One such proposal has recently emerged from a study of the Supreme Court's caseload by a distinguished group of lawyers and scholars. I want to take this opportunity to set forth my reaction to their proposal.

In its recently published and widely publicized report, ${ }^{1}$ the Study Group on the Case Load of the Supreme Court, often referred to as the Freund Committee, recommends a number of far-reaching changeschanges that would surely rank in importance with the creation of the Circuit Courts of Appeals in 1891, and with the reduction of the

$\dagger$ Associate Justice, United States Supreme Court. This paper was delivered as an address before the First Circuit Judicial Conference, Portsmouth, New Hampshire on May 23, 1973.

I Study Group on the Case Load of the Supreme Court, federal Judicial Center, REPORT (December, 1972) [hereinafter cited as REPORT]. 
Court's mandatory appellate jurisdiction in 1925. Many of the recommendations seem to me entirely sound. In particular, I share the Study Group's view that the existence of two distinct lines of access to the Supreme Court, appeal and certiorari, can no longer be justified. Direct appeals to the Supreme Court, whether from a one-judge court under the antitrust Expediting Act or from a three-judge court convened to consider the constitutionality of a state or federal statute, are my special candidates for repeal, and it is encouraging that Congress is now considering such legislation. These cases consume a disproportionate amount of the limited time available for oral argument. Yet we are regularly constrained to grant review, not so much because the question presented is especially important or because the District Court may well have erred, but rather because we are reluctant to deprive the losing litigant of any opportunity for appellate review of the trial court's decision. Since the policy considerations that gave rise to the distinction between review by appeal and review by writ of certiorari have long since lost their force, I support most enthusiastically the proposal to abandon the appellate jurisdiction and leave a writ of certiorari as the only means of obtaining review by the Supreme Court. This proposal is not, however, the major focus of the Study Group's report; it is only incidental to a far more important and far more controversial recommendation. Having reviewed the size of our docket and considered the burden of screening out the cases that will be set for plenary review, the Study Group concludes that a fundamental restructuring of the federal judiciary is warranted. Specifically, they propose the creation of a National Court of Appeals, made up of seven United States circuit judges, who would assume upwards of 90 percent of the screening burden that now falls to the Supreme Court. That proposal seems to me fundamentally unnecessary and ill-advised, and I strongly hope that Congress will reject it.

As envisioned by the Study Group, the National Court of Appeals would have two major functions. First, it would assist the Supreme Court in selecting the cases that will be set for oral argument and plenary review. It is our current practice to hear, in the course of a Term, between 150 and 200 cases, carefully selected from the 3,500 to 4,000 applications for review that we annually receive. It may interest you that we do not set a quota of 150 to 200 cases: our procedures operate annually to produce that number without regard to the actual number of appeals and petitions that may be docketed in a particular Term. Under the proposed scheme, all applications for review would be channelled through the National Court of Appeals, and that Court would screen out approximately seven-eighths of the cases filed. Thus, 
each year that Court would pass up to the Supreme Court some 400 to 500 cases, and it is from that group of cases that we would choose the 150 or 200 that would be set for argument. The decision by the $\mathrm{Na}$ tional Court of Appeals to deny access to the Supreme Court would be final and unreviewable by the Supreme Court, although it would apparently be possible for the Supreme Court to grant certiorari in any given case prior to the screening decision of the National Court of Appeals. Second, the National Court of Appeals would be charged with the task of resolving on the merits certain conflicts between circuits, except where the conflict concerns a question of substantial importance. The decision of the National Court of Appeals, reached after oral argument and the submission of briefs, would also be unreviewable by the Supreme Court.

Much has already been said about the Study Group's proposal, ${ }^{2}$ and I expect that much more will appear in the coming months. For that reason, I see no need for me to touch every base and present my views on every argument for and against the proposal. I do not plan to discuss, for example, the argument that the plan would violate the constitutional provision establishing "one Supreme Court,"3 or the argument that the assignment to serve on the Court would affront the intellect and patience of a United States circuit judge. Nor will I discuss the drawbacks of having a new court decide finally and on the merits certain supposedly unimportant questions as to which the circuits are in conflict. Others have fully discussed those questions. But my now almost seventeen years service as an Associate Justice of the Supreme Court does afford me an unusual perspective on the proposal, and I am anxious to describe to you what seem to me two glaring defects in the plan. First, its fundamental premise that "consideration given to the cases actually decided on the merits is compromised by the pressures of processing the inflated docket of petitions and appeals" 4 is entirely unsupportable. Contrary to the Study Group's assumption, the Supreme

2 See, e.g., Bickel, The Overworked Court: A Reply to Arthur J. Goldberg, THE NEw Republic, February 17, 1973, at 17-18; Address by Chief Justice Warren Burger to the Fiftieth Annual Meeting of the American Law Institute, May 16, 1973, reported in 41 U.S.L.W. 2627; Freund, Why We Need the National Court of Appeals, 59 ABAJ 247 (1973); Goldberg, One Supreme Court, ThE NEW RePublic, February 10, 1973, at 14-16; Gressman, The National Court of Appeals: A Dissent, 59 ABAJ 253 (1973); Lewin, Helping the Court with Its Work, THE NEw RepubLic, March 3, 1973, at 15-19; Poe, Schmidt \& Whalen, $A$ National Court of Appeals: $A$ Dissenting View, 67 Nw. U.L. REv. 842 (1973); Address by Earl Warren to the Association of the Bar of the City of New York, May 1, 1973; Westen, Book Review, NEw YoRk Review of Books, February 22, 1973, at 29 .

3 U.S. Const. art III, § I.

4 REPORT, supra note 1 , at 6. 
Court is not overworked. Indeed, my law clerks tell me each year that the burden on the District and Circuit Courts with which they served before coming to me is no less substantial than the burden on the Supreme Court. Our docket has most definitely not swollen to a point where the burden of screening cases has impaired our ability to discharge our other vital responsibilities. Second, the Study Group has regrettably misconceived both the nature and the importance of the screening pron cess. Even if it were as time-consuming and difficult as the Study Group believes, that would underscore, not diminish, its importance. It is a task that should, I am convinced, be performed only by the Members of the Court. I hope I can demonstrate to you tonight that the removal of seven-eighths of that function from the Supreme Court would substantially impair our ability to perform the responsibilities conferred on us by the Constitution.

At the outset, I want to examine the Study Group's assumptions concerning the present work load of the Supreme Court. They observe, and I fully agree, that "the indispensable condition for discharge of the Court's responsibility is adequate time and ease of mind for research, reflection, and consultation in reaching a judgment, for critical review by colleagues when a draft opinion is prepared, and for clarification and revision in light of all that has gone before." But insofar as that observation implies that the screening function is so time-consuming and onerous that it imperils existence of the "indispensable condition," I emphatically disagree. It is true, of course, that the number of cases docketed has increased greatly over the past thirty or forty years. There were 3,643 cases filed with the Court during the 1971 Term as the Study Group Report itself points out, and the present indication is that the total filings during the present 1972 Term will be within 1 percent of that figure. This is twice as many as were filed in my first Term seventeen years ago, and $31 / 2$ times the number filed in 1935, and by itself, those statistics might lead one to believe that the Court is surely in need of help. But to concentrate merely on raw statistics, as the Study Group seems principally to have done, is misleading and $I$ think that is especially true in this situation. As one critic has observed: "Raw statistics as to case filings ... are but the starting point for identifying and evaluating the real workload of the Court. How much time is actually spent by the nine Justices and their law clerks in screening cases? How many of the cases are easily and quickly disposed of, and how many require more prolonged consideration? If it be true, as various Justices have indicated, that more than 60 percent of the paid cases 
and 90 percent of the in forma pauperis cases, are utterly without merit for review purposes, cannot these petitions for review be denied with a minimum of time and effort? How many cases are actually discussed at the Court's conferences? None of these questions or their answers are found in the [Study Group] Report."6 The answers to these questions are critical to an evaluation of the proposal and I shall undertake to answer them from the vantage point of my service on the Court. For we ought not replace present procedures if there is no pressing problem justifying their replacement. And I do not think that there is such a problem.

Let me begin by explaining briefly the timetable and the procedure used by the Court to screen 3,600 cases submitted for review. As cases are filed with the Court, they are collected by the Clerk's Office and eventually placed on a conference agenda. The agenda, together with the relevant papers as to the cases listed thereon, is circulated to the various chambers approximately two weeks prior to the scheduled conference date. We have about thirty scheduled conferences each Term. Approximately half of the cases are paid filings, with the other half being in forma pauperis filings. The ratio of petitions for certiorari to appeals is about 9 to 1 , the vast majority of the appeals being among the paid filings.

The method of screening the cases differs among the individual Justices, and thus I will confine myself to my own practice. That practice reflects my view that the screening function is second to none in importance-a point I shall touch upon more fully a little later. I try not to delegate any of the screening function to my law clerks and to do the complete task myself. I make exceptions during the summer recess when their initial screening of petitions is invaluable training for next Term's new law clerks. And I also must make some few exceptions during the Term on occasions when opinion work must take precedence. When law clerks do screening, they prepare a memorandum of not more than a page or two in each case, noting whether the case is properly before the Court, what federal issues are presented, how they were decided by the courts below, and summarizing the positions of the parties pro and con the grant of the case.

For my own part, I find that I don't need a great amount of time to perform the screening function-certainly not an amount of time that compromises my ability to attend to decisions of argued cases. In a substantial percentage of cases I find that I need read only the "Questions Presented" to decide how I will dispose of the case. This is certainly

6 Gressman, supra note 2, at 254. 
true in at least two types of cases-those presenting clearly frivolous questions and those that must be held for disposition of pending cases. Because of my familiarity with the issues of pending cases, the cases to be held are, for me, easily recognizable. For example, we heard argument early this Term in eight obscenity cases because we decided to undertake a general re-examination of that subject. Every agenda since then has included several cases of conviction or injunction under state obscenity laws and I simply mark those cases "hold." Similarly, with other cases I can conclude from a mere reading of the question presented that for me at least the question is clearly frivolous for review purposes. For example, during recent weeks, I thought wholly frivolous for review purposes questions such as: "Are Negroes in fact Indians and therefore entitled to Indians' exemptions from federal income taxes?" "Are the federal income tax laws unconstitutional insofar as they do not provide a deduction for depletion of the human body?" "Is the 16th Amendment unconstitutional as violative of the 14th Amendment?" and only last week, "Does a ban on drivers turning right on a red light constitute an unreasonable burden on interstate commerce?"

Nor is an unduly extended or time-consuming examination required of many of the cases that present clearly nonfrivolous questions. For very often even nonfrivolous questions are simply not of sufficient national importance to warrant Supreme Court review. And after a few years of experience, it is fair to say that a Justice develops a "feel" for such cases. For example, when the question is whether a court of appeals in a diversity case correctly applied governing state law, or correctly directed entry of a judgment notwithstanding the verdict, the question of error, if any, ordinarily does not fall within the area of questions warranting Supreme Court review. As to cases where my initial reading of the questions presented suggests to me that the case may merit Supreme Court review-the special "feel" one develops after a few years on the Court enables one to recognize the cases that are candidates for such review. I need not spend much time examining the papers in depth when the questions strike me as worthy of review, or at least as warranting conference discussion.

After examining or having law clerks examine each of the cases on the week's agenda, each Justice advises the Chief Justice of the cases that he wishes to have stricken from the agenda and laid over to a later date so that further views can be requested of the parties or of an interested nonparty such as the Solicitor General. Several days before conference, the Chief Justice circulates a "Discuss List" that designates the cases on the agenda that he believes are worthy of discussion at conference. Any Justice who wishes to add cases to the "Discuss List" can do so simply by 
making such a request. On the day before conference, the completed "Discuss List" is circulated to the individual chambers and the papers and memoranda relating to those cases are collected and taken to the conference room.

The conferences themselves are ordinarily held on Friday and usually last the better part of the day, with much of the time devoted to discussion of motions and of argued cases and the remainder of the time to the discussion of cases seeking plenary review. The initial conference at the beginning of the Term lasts several days and is devoted exclusively to the discussion of appeals and petitions listed on the summer conference agenda. This agenda contains approximately one-fourth, or about 900 , of the total cases filed during the Term and thus much of the Term's screening work is completed even before the Term actually begins. Up to 300 cases are discussed over the several days of the initial conference; at a regular Friday conference during the Term, the number of cases discussed may vary from as few as 10 to as many as 30 or 40 . Overall, however, approximately only 30 percent of the docketed cases are discussed at conference. In other words, the Court is unanimously of the view in 70 percent of all docketed cases, that the questions sought to be reviewed do not even merit conference discussion. That has proved to be true throughout my time on the Court and a check I made two weeks ago shows that it will be true this Term.

I should emphasize here that the longer one works at the screening function, the less onerous and time-consuming it becomes. I can state categorically that I spent no more time screening the 3,643 cases of the 1971 Term than I did screening half as many in my first Term in 1956. Unquestionably, the equalizer is experience, and for experience there can be no substitute-not even a second court. I subscribe completely to the observation of the late Mr. Justice Harlan that "Frequently the question whether a case is 'certworthy' is more a matter of 'feel' than of precisely ascertainable rules."' A commentator expressed the same thought this way: "[The Court's] present monitoring of all cases on the docket gives the Court a feel for the subjects of its ultimate judicial administration powers and an intuitive knowledge of when and where it is necessary to execute those powers." I fear that the Study Group gave insufficient weight to this vital fact in assuming that inflated numbers of appeals and petitions must inevitably make the screening function a more onerous and time-consuming burden.

Moreover, the proposal that a National Court of Appeals be created

7 Harlan, Manning the Dikes, Eighteenth Annual Cardozo Lecture before the Association of the Bar of the City of New York, October 28, 1958, at 16.

8 Gressman, supra note 2 , at 257. 
to ease the Supreme Court's workload may properly be challenged, not only with respect to the Study Group's understanding of that workload, but also with regard to its understanding of the nature of the screening process itself. As I have previously indicated, approximately 30 percent of all cases docketed annually (that means in this Term, 1,100 cases) are placed on the "Discuss List" each Term. Under this system, a single Justice may set a case for discussion at conference and, in many instances, that Justice succeeds in persuading three or more of his colleagues that the case is worthy of plenary review. Thus, the existing system provides a forum in which the particular interests or sensitivities of individual Justices may be expressed, and therefore assures a flexibility that is essential to the effective functioning not only of the screening process but also of the decisional process of which it is an inseparable part.

Much of this flexibility would be lost, however, if the scheme advanced by the Study Group were to be adopted. As envisioned by its proponents, the National Court of Appeals could certify a case to the Supreme Court only if three of its seven judges concurred. It is estimated that about 400 cases per Term would be passed on to the Supreme Court in this manner for final consideration. As a result, each year the Justices of the Supreme Court would be denied the opportunity even to consider the merits of approximately 700 cases that presently would be deemed of sufficient importance to warrant full debate at conference. This loss of flexibility in the screening process would necessarily have a substantial and detrimental effect upon the functions and responsibilities of the Court.

Similarly, an artificial limitation of the Supreme Court's docket to only 400 cases per year would seriously undermine the important impact dissents from denial of review frequently have had upon the development of the law. Such dissents often herald the appearance on the horizon of a possible reexamination of what may seem to the judges of the National Court of Appeals to be an established and unimpeachable principle. Indeed, a series of dissents from denials of review played a crucial role in the Court's reevaluation of the reapportionment question and the question of the application of the Fourth Amendment to electronic searches. Actually, every Justice has strong feelings about some constitutional view that may not yet command the support of a majority of the Court. For example, I thought that the Court was quite wrong in adopting "same evidence" rather than "same transaction" as the test of "same offense" for the purposes of double jeopardy. The question has recurred in case after case since the Court made that choice a few years ago. In each instance I and two of my colleagues have 
recorded our continued adherence to my minority view. Another example is the view shared by Mr. Justice Douglas with the late Mr. Justice Black in obscenity cases. They dissented in 1957 from the holding that obscenity does not enjoy First Amendment protection, and in every obscenity case since then Mr. Justice Douglas and, until his death, Mr. Justice Black, recorded their dissent from applications of the holding that obscenity is not protected speech. Only a brave man would say that their view could never prevail in the Court. The history of their dissents that have become law in cases involving reapportionment, the right to counsel, and the application of the Bill of Rights to the States are too fresh in mind to ignore. The creation of a National Court of Appeals that would certify the 400 "most reviewworthy" cases to the Court each Term would inevitably sacrifice this invaluable aid to constitutional adjudication by denying certification in cases that might otherwise afford appropriate vehicles for such dissents.

Moreover, the assumption that the judges of the National Court of Appeals could accurately select the 400 "most reviewworthy" cases wholly ignores the inherently subjective nature of the screening process. The cases docketed each Term cannot simply be placed into a computer that will instantaneously identify those that are "most reviewworthy." And this is particularly true with respect to distinctions among the 1,100 or so cases presently deemed to be of sufficient "reviewworthiness" to merit discussion at one of our weekly conferences.

Indeed, a question that is "substantial" for me may be wholly "insubstantial" to some, perhaps all the rest, of my colleagues. For example, I have long thought that the Court should decide the intensely controversial question whether the President's authority to prosecute hostilities in Indo-China is a justiciable question. I and two of my colleagues have stated as much in dissents from denial of review. Yet others feel strongly that the issue is so clearly nonjusticiable as to be utterly "insubstantial."

For the more statistically oriented, the subjective nature of the decision whether a particular case is of sufficient "importance" to merit plenary consideration is amply demonstrated by the voting pattern of the Justices in the screening process. Under our rules, a case may be granted review only if at least four of the nine Justices agree that such review is appropriate. It is noteworthy that, of the cases granted review this Term, approximately 60 percent received the votes of only four or five of the Justices. In only 9 percent of the granted cases were the Justices unanimous in the view that plenary consideration was war-

o REPORT, supra note 1 , at 47 . 
ranted. Thus, insofar as the key determinant is the "substantiality" of the question presented, there can be no doubt that the appraisal is necessarily a subjective one. And I share the concern voiced by Chief Justice Warren who warned: "[T]he delegation of most of the screening process to the National Court of Appeals would mean that the certiorari 'feel' of the rotating panels of that court would begin to play a vital role in the ordering of our legal priorities and in the control of the Supreme Court docket. More than that, this lower court 'feel' would be divorced from any intimate understanding of the concerns and interests and philosophies of the Supreme Court Justices; and that 'feel' could reflect none of the many other intangible factors and trends within the Supreme Court that often play a role in the certiorari process." 10 That observation effectively exposes the fallacy of the suggestion of the Study Group that "the Supreme Court's readiness to reopen what had seemed to be settled issues, its impatience with, or its interest in, one or another category of cases-all this we think would communicate itself to the National Court of Appeals, and would be acted upon."11

In response to these objections, it might of course be suggested that the National Court of Appeals certify to the Supreme Court, not 400 cases per Term, but, rather, all 1,100 or so cases normally placed on the "Discuss List." As I have already indicated, however, by far the greatest portion of the Court's time and energy presently devoted to the screening process is concentrated, not in the selection of cases to be discussed at conference, but, rather, in the selection from that group of cases of the 150 to 200 cases that will be granted plenary review each Term. Thus, even if the judges of the National Court of Appeals could accurately identify all or most of the cases that normally would be placed on the "Discuss List," such a scheme would inevitably prove virtually useless in terms of administrative efficiency.

Finally, it should be noted that the Study Group's recommendation that the breadth of the Court's screening function be curtailed rests in part upon what I consider to be the mistaken assumption that the screening function plays only a minor and separable part in the exercise of the Court's fundamental responsibilities. In my view, the screening function is inextricably linked to the fulfillment of the Court's essential duties and is vital to the effective performance of the Court's unique mission "to define the rights guaranteed by the Constitution, to assure the uniformity of federal law, and to maintain the constitutional distribution of powers in our federal union."12

10 Warren, supra note 2, at 19-20 .

11 REPORT, supra note 1 , at 23.

$12 I d$. at 1 . 
The choice of issues for decision largely determines the image that the American people have of their Supreme Court. The Court's calendar mirrors the everchanging concerns of this society with ever more powerful and smothering government. The calendar is therefore the indispenable source for keeping the Court abreast of these concerns. Our Constitution is a living document and the Court often becomes aware of the necessity for reconsideration of its interpretation only because filed cases reveal the need for new and previously unanticipated applications of constitutional principles.

For example, the Due Process Clauses provide that no person shall "be deprived of life, liberty or property without due process of law." The interest of the defaulting conditional sales purchaser in the refrigerator or kitchen stove or bedroom furniture that he bought on time clearly does not constitute "property" in the traditional sense of the word. Similarly, welfare benefits, automobile driver's licenses, retail liquor licenses, and the like were traditionally viewed as "statutory entitlements," rather than as "property." Vast societal changes over the past few decades, however, have substantially altered the function and importance to the individual of these previously unprotected interests. A long series of seemingly unimportant cases filed in the Court over a period of years gradually generated an awareness of these societal changes and of the consequent need for constitutional reinterpretation. As a result, recent construction of the Due Process Clauses requires government to afford notice and hearing before terminating "statutory entitlements" or repossessing goods. Another example may be seen in the area of criminal procedure. The Sixth Amendment's guarantee of the "Assistance of Counsel for his defense" is in terms applicable "in all criminal prosecutions." Are police interrogations or preliminary hearings part of the "criminal prosecution" for the purposes of this guarantee? The Court has held that they are in light of the serious abuses revealed in cases that reached our docket.

I could readily cite other instances, but these will suffice. As has been said, if the Study Group's proposal severely to circumscribe the Court's choice of issues were adopted: "The Supreme Court, by not even being aware of more than 3,200 cases on its docket, would be isolated from many nuances and trends of legal change throughout the land."13 The point is that the evolution of constitutional doctrine is not merely a matter of hearing arguments and writing opinions in cases granted plenary review. The screening function is an inseparable part of the whole responsibility; to turn over seven-eighths of that task to a National

13 Gressman, supra note 2, at 257. 
Court of Appeals is to rent a seamless web. I expect that only a Justice of the Court can know how inseparably intertwined are all the Court's functions, and how arduous and long is the process of developing the sensitivity to constitutional adjudication that marks the role. One enters a new and wholly unfamiliar world when he joins the Supreme Court of the United States, and this is as true of a Justice who comes from a federal court of appeals as it is of a Justice, like me, who came from a state supreme court. I say categorically that no prior experience, including prior judicial experience, prepares one for the work of the Supreme Court. I have sat with six colleagues appointed from federal courts of appeals and can confirm from my own experience how very right Mr. Justice Frankfurter was when he said ". . . even Justices who have come to the Court from a longish and conspicuously competent tenure on the lower federal courts do not find the demands of the new task familiar." 14 The initial confrontation on the United States Supreme Court with the astounding differences in function and character of role, and the necessity for learning entirely new criteria for decisions, can be a traumatic experience for the neophyte. How much more traumatic and difficult must be the task of the National Court of Appeals composed of rotating Circuit Judges required to do major Supreme Court work without ever being afforded the slightest glimpse of the whole picture of a Justice's function. It is not only that constitutional principles evolve over long periods and that one must know the history of each before he feels competent to grapple with their application in new contexts never envisoned by the Framers. It is also that he must acquire an understanding of the extraordinarily complex factors that enter into the distribution of judicial power between state and federal courts and other problems of "Our Federalism." The screening function is an indispensable and inseparable part of this entire process, and it cannot be curtailed without grave risk of impairing the very core of the extraordinary function of the Supreme Court.

Justice Goldberg has rightly said that "[ $t]$ he power to decide cases presupposes the power to determine what cases will be decided."16 I agree too that "[a]Iso presupposed ... [is] ... the more subtle power to decide when, how, and under what circumstances an issue should or should not be accepted for review.... Delegating to an outside body any significant exercise of the Supreme Court's discretionary power conceivably could injure the delicate interplay of the discretionary forces

14 F. Frankfurter, OF LaW and Life and Other Things that Matter 88 (P. Kurland ed. 1965).

15 Goldberg, The Case Against a National Court of Appeals, Washington Post, Jan. 6, 1973, at A-14, col. 4 . 
that underlie virtually every aspect of the Court's jurisdiction. Power once lodged in a given court must be totally retained, not divided, not delegated."16

The Study Group rejected a suggestion that the Court form a small senior staff to perform the screening function and recommend dispositions to the Court. The stated reason given was that "If . . . the scheme were to operate 'successfully,' so that in practice staff recommendations were accepted in a large number of cases as a matter of course and an acknowledged gap were thus to be opened between function and responsibility in the denial of certiorari and the dismissal of appeals, then we fear that public confidence in the Court would be impaired."17 One must ask, if delegation of the screening function to a staff empowered only to recommend dispositions threatens impairment of public confidence in the Court, is there not an incomparably greater threat in a delegation of that function to seven courts of appeals judges empowered finally to shut off the Supreme Court from access to seveneighths of its own docket? For as two members of the Study Group, Professors Freund and Bickel, have reminded us, when Justice Brandeis was asked how he explained the great prestige of the Court, he replied, "Because we do our own work."18

16 Gressman, supra note 2, at 256.

17 RePorr, supra note 1, at 16.

18 Bickel, supra note 2 , at 17 . 